\title{
Determinan Perilaku Ibu Hamil Melakukan Pemeriksaan Kehamilan (Antenatal Care) Pada Masa Pandemi Covid -19
}

\author{
Yenni Ariestanti, Titik Widayati, Yeny Sulistyowati \\ Universitas Respati Indonesia \\ yariestanti@yahoo.com
}

\begin{abstract}
Abstrak
Dalam situasi pandemi COVID-19 ini, banyak pembatasan hampir ke semua layanan rutin termasuk pelayanan kesehatan maternal dan neonatal. Seperti ibu hamil menjadi enggan ke puskesmas atau fasiltas pelayanan kesehatan lainnya karena takut tertular, adanya anjuran menunda pemeriksaan kehamilan dan kelas ibu hamil Kurangnya kunjungan ANC ini bisa menyebabkan bahaya bagi ibu maupun janin seperti terjadinya perdarahan saat masa kehamilan karena tidak terdeteksinya tanda bahaya. Tujuan penelitian ini adalah Menganalisis Determinan yang berhubungan dengan perilaku ibu hamil dalam melaksanakan pemeriksaan kehamilan pada masa pandemi Covid 19 di BPM Bidan "R" tahun 2020. Penelitian ini dilakukan dengan metode Survey analitik menggunakan pendekatan cross sectional,sampel dalam penelitian ini diperoleh dengan cara Accidental Sampling sejumlah 45 Ibu hamil trimester 3 yang melakukan ANC. Hasil penelitian mengunakan analisis Chi Square menunjukan nilai $\mathrm{P}<0,05$ adalah terdapat hubungan yang siqnifikan antara perilaku ibu hamil melakukan ANC dengan Umur,Pendidikan, Pengetahuan, Sikap, dan Fasilitas Kesehatan, variabel yang tidak berhubungan adalah pekerjaan ibu serta Dukungan Suami.Pandemi Covid 19 tidak menghalangi ibu hamil melakukan Pemeriksaan Kehamilan secara rutin.

Kata Kunci : Perilaku Ibu Hamil, ANC, Umur, pendidikan, pengetahuan,sikap dan Fasilitas kesehatan.
\end{abstract}

\begin{abstract}
In this COVID-19 pandemic situation, there are many restrictions to almost all routine services including maternal and neonatal health services. For example, pregnant women are reluctant to go to health centers or other health care facilities for fear of contracting them, the recommendation to postpone pregnancy examinations and classes of pregnant women. Lack of ANC visits can cause harm to both the mother and the fetus, such as bleeding during pregnancy because no danger signs are detected. The purpose of this study was to analyze the determinants related to the behavior of pregnant women in carrying out pregnancy examinations during the Covid 19 pandemic at BPM Midwives "R" in 2020. This study was conducted using an analytical survey method using a cross sectional approach, the sample in this study was obtained by accidental method. Sampling of 45 trimester 3 pregnant women who did ANC. The results of the study using Chi Square analysis showed that the value of $P$ $<0.05$ was that there was a significant relationship between the behavior of pregnant women doing ANC with age, education, knowledge, attitudes, and health facilities, the variables that were not related were the work of the mother and the support of the husband. 19 does not prevent pregnant women from doing routine prenatal checks.
\end{abstract}

http://ejournal.urindo.ac.id/index.php/kesehatan

Article History :

Sumbitted 22 Desember 2020, Accepted 30 Desember 2020, Published 31 Desember 2020 


\section{Jurnal Bidang IImu Kesehatan}

Keywords: Pregnant Mother Behavior, ANC, Age, Education, Knowledge, Attitudes and Health Facilities.

\section{PENDAHULUAN}

Kematian ibu dan kematian Neonatal di Indonesia masih menjadi tantangan besar, apalagi pada saat situasi bencana.Indonesia sedang menghadapi bencana nasinal non alam COVID 19 sehingga pelayanan kesehatan maternal dan neonatal menjadi salah satu layanan yang terkena dampakbaik secara akses maupun kuaitas. dik Dikhawatirkan, hal ini menyebabkan adanya peningkatan morbiditas dan mortalitas ibu dan bayi baru lahir.(1)

Dalam situasi pandemi COVID-19 ini, banyak pembatasan hampir ke semua layanan rutin termasuk pelayanan kesehatan maternal dan neonatal. Seperti ibu hamil menjadi enggan ke puskesmas atau fasiltas pelayanan kesehatan lainnya karena takut tertular, adanya anjuran menunda pemeriksaan kehamilan dan kelas ibu hamil, serta adanya ketidaksiapan layanan dari segi tenaga dan sarana prasarana termasuk Alat Pelindung Diri.(1)

Salah satu solusi efektif dalam menurunkan Angka Kematian lbu (AKI) dan Angka Kematian Bayi (AKB) adalah dengan cara meningkatkan pertolongan persalinan yang dilakukan oleh tenaga medis terlatih yang disediakan oleh fasilitas pelayanan kesehatan. Di samping itu, dibutuhkan partisipasi serta kesadaran ibu terhadap pentingnya pemeriksaan kehamilan di fasilitas pelayana kesehatan (2)

Sampai saat ini, pengetahuan tentang infeksi COVID-19 dalam hubungannya dengan kehamilan dan janin masih terbatas dan belum ada rekomendasi spesifik untuk penanganan ibu hamil dengan COVID-19. Berdasarkan data yang terbatas tersebut dan beberapa contoh kasus pada penanganan Coronavirus sebelumnya (SARS-CoV dan MERS-CoV) dan beberapa kasus COVID-19, dipercaya bahwa ibu hamil memiliki risiko lebih tinggi untuk terjadinya penyakit berat, morbiditas dan mortalitas dibandingkan dengan populasi umum. Efek samping pada janin berupa persalinan preterm juga dilaporkan pada ibu hamil dengan infeksi COVID-19. Akan tetapi informasi ini sangat terbatas dan belum jelas apakah komplikasi ini mempunyai hubungan dengan infeksi pada ibu. Dalam dua laporan yang menguraikan 18 kehamilan dengan COVID-19, semua terinfeksi pada trimester ketiga didapatkan temuan klinis pada ibu hamil mirip dengan orang dewasa yang tidak hamil. Gawat janin dan persalinan prematur ditemukan pada beberapa kasus. Pada dua kasus dilakukan persalinan sesar dan pengujian untuk SARS-CoV-2 ditemukan negatif pada semua bayi yang diperiksa.(3).

ANC atau antenatal care merupakan perawatan ibu dan janin selama masa 


\section{Jurnal Bidang IImu Kesehatan}

kehamilan. Seberapa penting dilakukan kunjungan ANC? Sangat penting. Melalui ANC berbagai informasi serta edukasi terkait kehamilan dan persiapan persalinan bisa diberikan kebada ibu sedini mungkin. Kurangnya pengetahuan mengenai tanda bahaya kehamilan sering terjadi karena kurangnya kunjungan ANC. Kurangnya kunjungan ANC ini bisa menyebabkan bahaya bagi ibu maupun janin seperti terjadinya perdarahan saat masa kehamilan karena tidak terdeteksinya tanda bahaya.(4).

Pelayanan Kesehatan Masa Hamil bertujuan untuk memenuhi hak setiap ibu hamil memperoleh pelayanan kesehatan yang berkualitas sehingga mampu menjalani kehamilan dengan sehat, bersalin dengan selamat, dan melahirkan bayi yang sehat dan berkualitas

Edukasi kepada Ibu hamil, Ibu bersalin, Ibu menyusui dan pengasuh agar patuh untuk menggunakan masker ketika berkunjung ke fasilitas kesehatan, dan jujur menyampaikan status kesehatannya jika ternyata sudah didiagnosa sebagai Orang Dalam Pementauan (ODP), Pasien Dalam Pengawasan (PDP) atau terkonfirmasi COVID-19.(2)

Sampai saat ini juga masih belum jelas apakah infeksi COVID-19 dapat melewati rute transplasenta menuju bayi. Meskipun ada beberapa laporan dimana bayi pada pemeriksaan didapatkan pemeriksaan positif dengan adanya virus beberapa saat setelah lahir, tetapi penelitian ini perlu validasi lebih lanjut tentang transmisi ini apakah terjadi di dalam kandungan atau di postnatal.

Pemeriksaan kehamilan pertama kali dibutuhkan untuk skrining faktor risiko (termasuk Program Pencegahan Penularan HIV, Sifilis dan Hepatitis B dari ibu ke anak / PPIA). Oleh karena itu, dianjurkan pemeriksaannya dilakukan oleh dokter di fasilitas pelayanan kesehatan dengan perjanjian agar ibu tidak menunggu lama. Apabila ibu hamil datang ke bidan tetap dilakukan pelayanan ANC, kemudian ibu hamil dirujuk untuk pemeriksaan oleh dokter Kelas Ibu Hamil ditunda pelaksanaannya di masa pandemi COVID-19 atau dapat mengikuti kelas ibu secara online. 9. Tunda pemeriksaan pada kehamilan trimester kedua. Atau pemeriksaan antenatal dapat dilakukan melalui tele-konsultasi klinis, kecuali dijumpai keluhan atau tanda bahaya. 10. Ibu hamil yang pada kunjungan pertama terdetekdi memiliki faktor risiko atau penyulit harus memeriksakan kehamilannya pada trimester kedua.

Total terdapat 2.419 kasus positif yang ada di wilayah Jakarta Timur terhitung sejak hari Selasa (21/7/2020). Angka tersebut terdiri dari 75 orang dirawat, 507 Isolasi mandiri, sembuh sebanyak 1.705 dan meninggal sebanyak 132 sehingga .Ditengah pandemi global Covid -19 , sangat di butuhkan sinergitas seluruh tenaga kesehatan termasuk peran bidan dan perawat yang merupakan profesi yang mulia.

Peran bidan melaksanakan beberapa aksi inovasi, melakukan edukasi dalam 
memutus mata rantai perjalanan penularan dengan memberikan informasi pola hidup bersih ,rajin mencuci tangan, jaga jarak, menjauhi kerumunan dan melakukan penyemprotan disinfektan $\mathrm{Di}$ Era pandemi Covid -19 ada beberapa yang menutup PMB nya tetapi masih $72 \%$ masih aktif memberikan pelayanan dengan mengacu dan protokol kesehatan yang sudah di tetapkan.(5). salah satunya sehingga dapat mencegah penularan terutama Pada ibu hamil adalah Bidan Rosnawati.

BPM hj, Rosnawati terletak di puskesmas Cipayung jakarta timur merupakan salah satu tempat pelayanan kesehatan bagi ibu dan bayi yang cukup memadai dan profesional dan pelayanan yang diberikan yaitu pemeriksaan kehamilan, persalinan, nifas, KB, dan lain-lain. Sedangkan data kunjungan ibu hamil tercatat pada periode Januari-Desember yaitu ANC baru dan lama tercatat sebanyak 425 kunjungan ibu hamil berrti kunjungan rata@per bulan mencapai 35-40 kunjungan ( Data Rekam Medik Bps Bidan "R" tahun 2019 ) dan masa pandemi bpm tersebut sudah menjalankan protokol kesehatan yang diharapkan dapat membuat pasien nyaman untuk melakukan pemeriksaan kehamilan.sebagai perbandingan pada awal covid bulan maret 2020 terjadi penurunan jumlah ANC sebanyak 20 pasien/bulan dan era new normal mulai new normal yaitu 30 pasien/bulan sehingga peneliti ingin meneliti tentang perilaku ibu hamil dalam melakukan Pemeriksaan kehamilan (Antenatal Care)di BPM hj. Rosnawati tahun 2020

\section{Metode Penelitian}

\subsection{Tempat dan Waktu}

Penelitian dilakukan di BPM Bidan Rosnawati Waktu penelitian bulan maret -2 Oktober 2020

\subsection{Populasi dan Sampel Penelitian}

Populasi pada penelitian ini adalah seluruh pasien ibu hamil Trimester 3 yang datang melakukan pemeriksaan kehamilan 6 bulan (maret-September 2020) berjumlah 300 dengan rata2 per bulan 40-50 pasien, pegambilan sampel Accidental sampling selama 1 bulan ( 3 september-Oktober 2020 ) berjumlah 45 orang dan semua dijadikan sampel penelitian/total populasi.

\subsection{Rancangan Penelitian}

Penelitian ini merupakan penelitian survei analitik dengan menggunakan pendekatan kuantitatif dengan rancangan cross sectional study.

\subsection{Etika Penelitian}

Peneliti telah melakukan uji etik proposal penelitian dan telah keluar asil kaji etik pada bulan 28 Agustus 2020,sehingga turun lapangan dilakukan setelah uji etik dilaksanakan.

\subsection{Teknik dan Alat Pengumpulan Data}

Data untuk variabel dependen adalah perilaku ibu hamil melakukan ANC selama Pandemi Covid 19, sedangkan variabel Independenya berupa

Umur, pendidikan, pekerjaan, pengetahuan,sikap, dukungan suami dan fasilitas kesehatan terkait Covid 19.alat pengumpul data mengunakan 
kuisioner yang dibagikan langsung kepada pasien mengunakan protokol kesehatan mengunakan masker,jaga jarak dan dilakukan pengecekan setelah jawaban diisi oleh pasien yan sebelumnya mengisi informed consent.

\subsection{Teknik Analisis Data}

Analisis univariat dilakukan untuk mengetahui distribusi frekuensi dan variabel independen/dependen. Setelah pengolahan data selanjutnya dilakukan analisis dengan analisis univariat. Analisis bivariat bertujuan untuk melihat dua variabel yang diduga

\section{Hasil}

\subsection{Hasil Analisis Univariat}

berhubungan atau berkolerasi. Uji statistik yang dilakukan adalah Chi Square dengan bantuan perangkat lunak, program statistik, di hasilkan Odds Ratio yang di gunakan untuk melihat hubungan variabel independen dengan variabel dependen.

\begin{tabular}{|c|c|c|c|}
\hline No & Variabel & Jumlah & Persentase \\
\hline \multirow[t]{3}{*}{1.} & $\begin{array}{l}\text { Perilaku ibu } \\
\text { hamil melakukan } \\
\text { ANC }\end{array}$ & & \\
\hline & Tidak Rutin & 12 & 26,7 \\
\hline & rutin & 33 & 73,3 \\
\hline \multirow[t]{3}{*}{2.} & Umur Ibu & & \\
\hline & Remaja & 11 & 24,4 \\
\hline & Dewasa & 34 & 75,6 \\
\hline \multirow[t]{3}{*}{3.} & Pendidikan Ibu & & \\
\hline & Rendah & 15 & 33,3 \\
\hline & Tinggi & 30 & 66,7 \\
\hline \multirow[t]{3}{*}{4.} & Pekerjaan Ibu & & \\
\hline & Bekerja & 14 & 31,1 \\
\hline & Tidak Bekerja & 31 & 68,9 \\
\hline \multirow[t]{3}{*}{5.} & Pengetahuan Ibu H & amil & \\
\hline & Rendah & 8 & 17,8 \\
\hline & Tinggi & 37 & 82,2 \\
\hline \multirow[t]{3}{*}{6.} & Sikap & & \\
\hline & Negatif & 17 & 37,8 \\
\hline & Positif & 28 & 62,2 \\
\hline \multirow[t]{3}{*}{7.} & Dukungan Suami & & \\
\hline & Tidak Mendukung & 13 & 28,9 \\
\hline & Mendukung & 32 & 71,1 \\
\hline \multirow[t]{4}{*}{8.} & $\begin{array}{l}\text { Fasilitas Kesehatar } \\
\text { pencegahan penul } \\
19\end{array}$ & $\begin{array}{l}\text { BPM dala } \\
\text { ran Covic }\end{array}$ & \\
\hline & Tidak tersedia & 17 & 37,8 \\
\hline & Tersedia & 28 & 62,2 \\
\hline & Total & 45 & 100 \\
\hline
\end{tabular}


Sumber: Yenni A (2020)

terdapat $73,3 \%$ Ibu hamil yang melakukan pemeriksaan kehamilan secara rutin di Masa Pandemi Covid 19, ibu hamil yang berusia Dewasa 75,6\%, Pendidikan Ibu Hamil sebagian besar berpendidikan tinggi (66,7\%), Ibu Hamil sebagian tidak Bekerja atau IRT sebanyak 68,9\% ,sikap Ibu hamil sebagian besar memunyai sikap positif $71,1 \%$, Dukungan Suami sebagian besar mendukung ibuhamil melakukan ANC sebanyak 71,1\% dan Fasilitas Kesehatan tersedia oleh BPM dalam upaya pencegahan penularan Covid 62,2

\subsection{Hasil Analisis Bivariat}

Tabel 5. Hubungan Perilaku Ibu Hamil Melakukan ANC dengan Umur,Pendidikan Sikap, Pengetahuan,Pekerjaan, Dukungan Suami dan Fasilitas Kesehatan di BPM Bidan Rosnawati Tahun 2020

\begin{tabular}{|c|c|c|c|c|c|c|c|c|c|}
\hline \multirow{4}{*}{\multicolumn{2}{|c|}{ Variabel }} & \multicolumn{4}{|c|}{ Perilaku ibu Melakukan } & & & \multirow{4}{*}{$\begin{array}{c}\text { OR } \\
(95 \% \mathrm{Cl})\end{array}$} & \multirow{4}{*}{$\begin{array}{c}\mathrm{P} \\
\text { Value }\end{array}$} \\
\hline & & \multicolumn{4}{|c|}{ ANC } & & & & \\
\hline & & \multicolumn{2}{|c|}{ Tidak Rutin } & \multicolumn{2}{|c|}{ Rutin } & \multicolumn{2}{|c|}{ Total } & & \\
\hline & & $\mathrm{n}$ & $\%$ & $\mathrm{n}$ & $\%$ & $\mathrm{n}$ & $\%$ & & \\
\hline \multirow[t]{3}{*}{1.} & Umur & & & & & & & & \\
\hline & Remaja & 6 & 54.5 & 5 & 45.5 & 11 & 100 & $\begin{array}{c}5.600 \\
(1.277-24.54)\end{array}$ & 0.044 \\
\hline & Dewasa & 6 & 17,6 & 28 & 82,4 & 34 & 100 & & \\
\hline \multirow[t]{3}{*}{2.} & Pendidikan & & & & & & & & \\
\hline & Rendah & 8 & 53,3 & 7 & 46.7 & 15 & 100 & 7.429 & 0.013 \\
\hline & Tinggi & 4 & 13.3 & 26 & 86.7 & 33 & 100 & $(1.722-32.047)$ & \\
\hline \multirow[t]{3}{*}{3.} & Pekerjaan & & & & & & & & \\
\hline & Bekerja & 6 & 42.9 & 8 & 57.1 & 14 & 100 & 3.125 & 0.198 \\
\hline & Tidak Bekerja & 6 & 19.4 & 25 & 80.6 & 31 & 100 & $(0.783-12.466)$ & \\
\hline \multirow[t]{3}{*}{4.} & Pengetahuan & & & & & & & & \\
\hline & Cukup & 5 & 62.5 & 3 & 37.5 & 8 & 100 & 7.143 & 0.037 \\
\hline & Baik & 7 & 18.9 & 30 & 81.1 & 37 & 100 & $(1.370-37.228)$ & \\
\hline \multirow[t]{3}{*}{5.} & Sikap & & & & & & & & \\
\hline & Negatif & 8 & 47.1 & 9 & 52.9 & 17 & 100 & 5.333 & 0.039 \\
\hline & Positif & 4 & 14.3 & 24 & 85.7 & 28 & 100 & $(1.284-22.150)$ & \\
\hline \multirow[t]{4}{*}{6.} & $\begin{array}{l}\text { Dukungan } \\
\text { Suami }\end{array}$ & & & & & & & & \\
\hline & Tidak & 6 & 46.2 & 7 & 53.8 & 13 & 100 & 3.714 & 0.130 \\
\hline & Mendukung & & & & & & & (0.910-15.154) & \\
\hline & Mendukung & 6 & 18.8 & 26 & 81.3 & 32 & 100 & & \\
\hline \multirow[t]{3}{*}{7.} & $\begin{array}{l}\text { Fasilitas } \\
\text { Kesehatan }\end{array}$ & & & & & & & & \\
\hline & Tidak & 1 & 5.9 & 16 & 94.1 & 17 & 100 & 0.097 & 0.035 \\
\hline & $\begin{array}{l}\text { tersedia } \\
\text { tersedia }\end{array}$ & 11 & 39.3 & 17 & 60.7 & 28 & 100 & $(0.011-0.836)$ & \\
\hline
\end{tabular}

\section{PEMBAHASAN}

http://ejournal.urindo.ac.id/index.php/kesehatan
1. Perilaku Ibu Hamil Melakukan ANC 
Penelitian yang dilakukan ini adalah penelitian untuk mengetahui determinan yang berhubungan dengan ibu hamil melakukan pemeriksaan ANC di masa Pandemi Covid 19.penelitian ini dilakukan di daerah jakarta timur dimana saat dilakukan penelitian Jakarta masih berada di Zona Merah dan dalam pemberlakuan New Normal.penelitian ini dilakukan dengan pemilihan Sampel secara Accidental sampling dan diperoleh responden sebesar 45 Ibu Hamil.

Berdasarkan hasil penelitian bahwa ibu hamil yang melakukan pemeriksaan ANC di masa pandemi Covid 19 yang tidak rutin melakukan ANC adalah12 $(26,7 \%)$, Rutin adalah 33 $(73,3 \%)$ hasil ini didapatkan dengan mencocokkan KMS ibu Hamil dengan keteraturan ibu melakukan ANC sesuai dengan Trimester Kehamilan dengan Depkes yaitu minimal 4 kali kunungan selama kehamilan.pada saat dilakukan penelitian ibu hamil mengunakan masker dan menjaga jarak serta memakai Handsanitiser yang disediakan BPM.

Pelayanan Kesehatan Masa Hamil bertujuan untuk memenuhi hak setiap ibu hamil memperoleh pelayanan kesehatan yang berkualitas sehingga mampu menjalani kehamilan dengan sehat, bersalin dengan selamat, dan melahirkan bayi yang sehat dan berkualitas.Edukasi kepada Ibu hamil, Ibu bersalin, Ibu menyusui dan pengasuh agar patuh untuk menggunakan masker ketika berkunjung ke fasilitas kesehatan, dan jujur menyampaikan status kesehatannya jika ternyata sudah didiagnosa sebagai Orang Dalam Pementauan (ODP), Pasien Dalam Pengawasan (PDP) atau terkonfirmasi COVID-19.(2)

Pada penelitian ini gambaran perilaku ibu hamil melakukan ANC adalah sebagian besar responden melakukan pemerikasaan kehamilan secara Rutin, sehingga walaupun adanya Pandemi Covid 19 ibu hamil beserta keluarga masih meakukan pemeriksaan kehamilan sehingga mampu menjalani kehamilan dengan sehat, bersalin dengan selamat, dan melahirkan bayi yang sehat dan berkualitas dan mendapatkan Edukasi terkait kehamilan dan kepatuhan terkait Protokol Kesehatan di masa Pandemi Covid agar Bayi dan Ibu Hamil sehat dan terlindung dari Virus Corona didukung oleh umur, pendidikan, pengetahuan yang tinggi.

\section{Umur lbu}

Semakin cukup umur maka tingkat kematangan dan kekuatan seseorang akan lebih matang dalam berpikir dan bekerja. Sedangkan usia ibu hamil adalah usia ibu yang diperoleh melalui pengisisan kuesioner. Dalam kurun waktu reproduksi sehat dikenal usia aman untuk kehamilan, persalinan, dan menyusui adalah 20-35 tahun. Umur ibu salah satu faktor penentu mulai proses kehamilan sampai persalinan. Mereka yang berumur kurang dari 20 tahundikhawatirkan mempunyai resiko yang erat dengan kesehatan reproduksinya.umur Menurut WHO, yang disebut remaja adalah mereka yang berada pada tahap transisi antara masa kanak-kanak dan dewasa. Batasan usia remaja menurut WHO adalah 11 sampai 24 tahun 
Berdasarkan Hasil penelitian ini adalah umur berhubungan secara Siqnifikan dengan perilaku Ibu hamil melakukan ANC (p:0.004:OR : 5.600(1.277-24.54) sebagian besar ibu melakukan pemeriksaan Kehamilan adalah berumur dewasa dan peluang ibu yang berumur dewasa adalah 5.600 kali melakukan ANC dibandingkan dengan berumur remaja.

Penelitian ini sejalan dengan penelitian putri (2013) Ada hubungan yang signifikan antara usia Ibu hamil terhadap kepatuhan ANC dengan $p$-value $=0,000<\alpha(0,05)$. Nilai tersebut disimpulkan bahwa ada hubungan yang signifikan antara usia Ibu hamil terhadap kepatuhan ANC di Puskesmas Suruh Kabupaten Semarang, Menurut penelitian Hikmah (2019) ada pengaruh umurDari hasil uji statistik, chisquare diperoleh nilai kemaknaan $p=0,036$ (< 0,05), maka dapat di simpulkan bahwa ada pengaruh umur terhadap pemeriksaan ANC di wilayah kerja Puskesmas Kebayakan Kabupaten Aceh Tengah Tahun 2019Menurut temuan peneliti ibu hamil dengan kategori umur tidak beresiko (20-35 tahun) lebih banyak dalam melakukan pemeriksaan ANC. Ibu yang tergolong usia 20-35 tahun memiliki kesiapan yang baik untuk hamil, dimana selama proses kehamilan diperlukan kematangan fisik, emosi maupun psikologi dari ibu hamil itu sendiri. Proses kehamilan perlu didukung oleh kesabaran, pemahaman dan juga keterampilan ibu dalam menjaga kehamilannya tetap berlangsung baik dan normal demi keselamatan dirinya dan juga janin yang dikandung. Berbeda dengan ibu yang hamil di usia 35 tahun yang sebenarnya sudah memiliki kematangan emosi maupun psikologi yang baik, namun karena pengalamannya yang dirasa cukup sering kali membuat ibu hamil tersebut lalai dalam melakukan pemeriksaan[ 19]

Menurut peneliti bahwa umur pada penelitian ini yang rutin melakukan pemeriksaan Kehamilan adalah usia dewasa lebih mempunyai peluang dibandingkan umur remaja disebabkan oleh kematangan fisik, emosional maupun psikologi ibu sendiri yang membuat ibu semakin sadar pentingnya melakukan pemeriksaan Kehamilan walaupun dimasa Pandemi Covid 19 didukung pula dari pengetahuan serta pendidikan mereka yang tergolong tinggi sehingga semakin dewasa umur wanita hamil sangat menetukan perilaku terkait kesehatan terutama pemeriksaan Kehamilan.

\section{Pendidikan}

Pendidikan merupakan kebutuhan dasar manusia yang sangat penting untuk mengembangkan diri, umumnya semakin tinggi Pendidikan seseorang semakin baik pula tingkat pengetahuannya. Seorang ibu yang berpendidikan tinggi akan berbeda tingkah lakunya dengan ibu yang berpendidikan rendah. Hal ini disebabkan ibu yang berpendidikan tinggi akan lebih banyak mendapatkan pengetahuan tentang pentingnya menjaga kesehatan terutama dalam keadaan hamil yang merupakan kondisi berisiko.

Berdasarkan penelitian ini pendidikan berhubungan secara siqnifikan dengan Perilaku Ibu Hamil melakukan ANC di BPM hj Rosnawati tahun 2020 dengan nilai(p:0.013; OR : 
7.429(1.722-32.047)), sebagian besar pendidikan responden dengan kategori tinggi(sma keatas) $66.7 \%$.

Penelitian ini sejalan dengan penelitian Inayah (2018) di Puskesmas Gamping 1 Sleman bahwa pendidikan berhubungan dengan keteraturan kunjungan ANC pada ibu hamil Trimester 3 dengan nilai $p: \mathbf{0 , 0 3 4} \mathrm{lbu}$ hamil yang memiliki pendidikan tinggi akan memeriksakan kehamilannya secara rutin untuk mengetahui bagaimana perkembangan janinnya. Seseorang yang berpendidikan tinggi memiliki rasa ingin tahu yang besar sehingga mendorong ibu hamil mencari tahu informasi mengenai kehamilannya serta menanyakan keluhankeluhan yang dirasakan selama kehamilanHal ini diperkuat dengan jumlah responden yang berpendidikan SMA sebanyak 24 responden (70,6\%). Dalam penelitian ini didapatkan ibu hamil yang memiliki pendidikan SMA yaitu $70,6 \%$, teratur dalam melakukan kunjungan ANC.[20]

Menurut peneliti bahwa seorang ibu yang mempunyai pendidikan tinggi akan mempunyai tingkah laku dan mempunyai pengetahuan yang tinggi terkait kesadaran melakukan ANC untuk kesehatan Ibu dan Bayinya karena pada saat tidak Pandemi saja banyak resiko yang akan dialami ibu apabila tidak berperilaku rutin dalam melakukan ANC selama kehamilan apalagi ditambah dengan adanya Pandemi ibu semakin sadar dan memberanikan diri melakukan ANC secara rutin dengan melakukan protokol kesehatan dan mencari tempat Praktik yang melindungi mereka saat melakukan pemeriksaan kehamilan.

\section{Pekerjaan}

Pekerjaan adalah kegiatan yang disukai maupun tidak disukai tetap dilakukan untuk menunjang kehidupan baik dirinya sendiri maupun keluarganya, dalam penelitian ini sebagian besar ibu yang tidak bekerja/IRT yang rutin melakukan ANC sebesar 68,9 \%, dan Variabel pekerjaan tidak berhubungan dengan Perilaku Ibu melakukan Pemeriksaan ANC (P:0,013)

Penelitian ini sejalan dengan penelitian Lumenpoouw(2017) tidak terdapat hubungan antara pekerjaan ibu dengan kunjungan antenatal care. $p$-value $=0,757(p>0,05)$ Hal tersebut dikarenakan hampir sebagian besar ibu yang tidak bekerja sebagai Ibu Rumah Tangga sehingga mereka memiliki banyak waktu luang untuk melakukan kunjungan antenatal care.

Menurut peneliti pekerjaan tidak ada hubungan dengan keteraturan melakukan ANC hal ini disebabkan karena ibu yang bekerjapun mempunyai kesadaran yang tinggi untuk elakukan pemeriksaan kehamilan dengan meluangkan waktu serta membuat janji dengan pihak BPM di masa Pandemi Covid ini sehingga bekerjapun tetap dapat melakukan Pemeriksaan ANC secara Teratur.

\section{Pengetahuan}

Berdasarkan Hasil penelitian dengan pengetahuan cukup adalah 37 responden $(82,2 \%)$ sedangkan dari 45 respondeng yang pengetahuannya baik 8 responden $(17,8 \%)$ dan perilaku baik adalah $(81,1 \%)$. hasil Hasil uji chi square di peroleh nilai P-value sebesar 0,037 yaitu $<\alpha(0,05)(O R=7,143)$ yang artinya ada 
hubungan antara pengetahuan dan perilaku Pengetahuan Ibu Hamil Melakukan Pemeriksaan Kehamilan (Antenatal Care) Pada Masa Pandemi Covid-19 Di BPM Hj. Rosnawati, S.ST, Tahun 2020. Ibu yang mempunyai pengetahuan yang baik memiliki peluang 7,143 kali melakukan perilaku pemeriksaan kehamilan/ANC di bandingkan yang berpengetahuan Cukup.

Hasil ini sesuai dengan penelitian yang dilakukan oleh Astuti (2014), yang menyatakan bahwa ada hubungan yang signifikan antara tingkat pengetahuan dengan kunjungan K4 pada ibu hamil di wilayah kerja Puskesmas Duren Kab.Semarang $(\rho=0,008<\alpha=0,05 ; O D=$ 15,0).[21]. Hasil ini juga sesuai dengan Syamsiah (2014), yang menyatakan bahwa ada hubungan antara pengetahuan dengan kunjungan ANC pada ibu hamil di Puskesmas Kecamatan Kembangan Jakarta Barat $(\rho=0,032<\alpha=0,05$; $\mathrm{OR}=3,83) \cdot 11$ Pengetahuan merupakan salah satu faktor yang mempengaruhi atau yang melatarbelakangi (predisposing factor) perubahan perilaku yang memberikan pemikiran rasional atau motivasi terhadap suatu kegiatan, juga sebagai faktor yang mempermudah terjadinya perilaku seseorang. Pada penelitian ini, perilaku yang dimungkinkan dipengaruhi oleh tingkat 47 pengetahuan adalah perilaku ketepatan kunjungan ANC di Puskesmas Rekas, Kabupaten Manggarai Barat 22

Menurut peneliti Perlunya peningkatan pengetahuan bagi ibu-ibu yang yang berpengetahuan cukup mengenai kehamilan dan persalinan melalui penyuluhan atau konsultasi dengan tenaga kesehatan, sehingga dapat menumbuhkan pengetahuan yang baik agar tercipta kualitas kehamilan yang baik walaupun dalam masa Pandemi Covid 19.

7. SIKAP

sikap itu dapat mempengaruhi perilaku lewat suatu proses pengambilan keputusan yang teliti dan beralasan. Secara sederhana teori ini menjelaskan bahwa seseorang akan melakukan suatu perbuatan apabila memandang perbuatan itu positif dan bila ia percaya bahwa orang lain ingin agar ia melakukannya. Sikap merupakan reaksi atau respon yang masih tertutup dari seseorang terhadap suatu stimulus atau objek. Allport (1954) menjelaskan bahwa sikap mempunyai tiga komponen pokok :Kepercayaan (keyakinan), ide, konsep terhadap suatu objek,Kehidupan emosional atau evaluasi terhadap suatu obje dan Kecenderungan untuk bertindak (tend to behave)[8]

berdasarkan Hasil uji chi square di peroleh nilai $(P=0,039)$ yaitu $<\alpha(0,05)$ yang artinya ada hubungan bermakna secara siqnifikan antara sikap dan perilaku Ibu Hamil Melakukan Pemeriksaan Kehamilan (Antenatal Care) Pada Masa Pandemi Covid-19 Di BPM Hj. Rosnawati, S.ST, Tahun 2020. nilai $(O R=5,333)$ ibu yang mempunyai sikap positif mempunyai peluang 5 kali mempunyai perilaku pemeriksaan kehamilan secara rutin dibandingkan dengan yang sikap negatif.

Hasil ini sejalan dengan penelitian yang dilakukan oleh Chaerunnisa (2014), yang 
menyatakan bahwa sikap berhubungan dengan pemanfaatan pelayanan antenatal care pada ibu hamil di Puskesmas Mamajang Kota Makasssar tahun $2014(\rho=0,043<\alpha=0,05)$. Hasil ini juga sejalan dengan penelitian yang dilakukan Fasiha (2017) ada hubungan sikap ibu hamil terhadap pentingnya Antenatal care dengan nilai $p$ value 0,039 . 48 Sikap merupakan reaksi atau respon yang masih tertutup dari seseorang terhadap suatu stimulus atau objek.. Dengan terbentuknya sikap yang positif terhadap pentingnya ANC ibu hamil dapat melakukan pemeriksaan kehamilan pada tenaga kesehatan sehingga dapat memantau kondisi ibu dan janin, sehingga cakupan K1 dan K4 tercapai sesuai target.

Menurut penelti bahwa sikap ibu hamil positif kecenderungan untuk memunyai perilaku yang positif sehingga perilaku itu memunculkan perbuatan untuk melakukan pemeriksaan kehamilan walaupun di masa Pandemi Covid 19 dikarenakan sikap positif muncul bisa karena fasilitas kesehatan yang lengkap kemudian kenyamanan tempat praktek kemudian secara pengetahuan ibu banyak mendapatkan beberapa informasi serta edukasi terkait pentingnya penjagaan kesehatan terutama pandemi covid dimana bidan praktik mengatur jarak penyediaan handsanitiser.sebaliknya sikap yang negatif apabila ditingkatkan terus pengetetahuan terkait ANC maka kemungkinan sikap akan berupah menjadi positif secara perlahan.

8. Dukungan Suami

$$
\text { Dukungan keluarga (suami) adalah }
$$
sikap, tindakan dan penerimaan keluarga, dalam hal ini suami atas kondisi istrinya yang hamil dengan segala konsekuensinya. Dukungan seorang suami terhadap istrinya yang hamil misalnya dengan menemani istri memeriksa kehamilannya, mengingatkan istri untuk rajin memeriksakan kehamilannya, dan sebagainya. Bagaimanapun keluarga, dalam hal ini suami merupakan orang paling dekat dengan ibu hamil (17)

Hasil penelitian uji statistic di peroleh $p$-value adalah $0,130>\alpha(0,05)$, sehingga dapat dinyatakan bahwa tidak ada hubungan yang signifikan antara dukungan suami dengan perilaku ibu hamil dalam melakukan pemeriksaan kehamilan/ANC di pada masa pandemic covid -19di BPM Hj. Rosnawati, S.ST Tahun 2020

Penelitian ini sejalan dengan penelitian Inayah (2018) di Puskesmas Gamping 1 Sleman bahwa tidak ada hubungan antara dukungan suami dengan keteraturan ANC dengan $p: 0,239$ Berdasarkan hasil observasi selama penelitian, ibu hamil yang melakukan pemeriksaan kehamilan sebagian besar ditemani oleh suami, tetapi suami tidak menemani hingga ke dalam ruang pemeriksaan.penelitian ini tiddak sejalan dengan penelitian Handayani terdapat hubungan antara dukungan suami tehadap kepatuhan ibu melakukan kunjungan antenatal care di poliklinik RSUD Koja Jakarta Utara dengan nilai $(p: 0,005) r=0,249$

Menurut asumsi peneliti dukungan suami seharusnya menjadikan ibu lebih rajin 
melakukan pemeriksaan kehamilan kemungkinan disini dukungan suami belum total diberikan kepada isteri hanya sebatas mengantar sampai ditempat tetapi kurang memastikan kondisi kehamilan dari isteri keterlibatan psikologis suami saat menerima pesan dari bidan dan penjagaan isteri terkait dengan Pandemi Covid bahwan ibu lebih rentan tertular Covid sehingga selain mengantar suami juga diharapkan selalu terlibat dalam kegiatan pemeriksaan kehamilan dan mengingatkan melakukan pemeriksaan kehamilannpengunaan protokol kesehatan ditempat pemeriksaan.

Berdasalkan Hasil uji statistic di peroleh $p$-value adalah $0,035<\alpha(0,05)$, sehingga dapat dinyatakan bahwa ada hubungan yang signifikan antara fasiitas kesehatan yang dimiliki oleh tempat praktek dengan perilaku ibu hamil melakukan pemeriksaan kehamilan (Antenatal Care) pada masa pandemic covid--19 di BPM Hj. Rosnawati, S.ST Tahun 2020.Hasil analisis lebih lanjut didapatkan $\mathrm{OR}=0,097$, artinya ketersediaan fasilitas kesehatan yang dimiliki oleh tempat praktek saat melakukan pemeriksaan kehamilan (Antenatal Care) memiliki peluang 0,097 kali menunjang perilaku ibu hamil rutin melakukan pemeriksaan Kehamilan di banding dengan tidak tersedia fasiitas kesehatan.

Dari hasil observasi peneliti bahwa tempat praktik selalu disterilkan secara rutin, kemudian menyediakan handsanitizer bagi pengunjung.belum ada penelitian yang menunjukan fasilitas pelayanan Covid berhubungan dengan keteraturan ibu hamil melakukan pemeriksaan kehamilan.

Menurut asumsi peneliti bahwa fasilitas kesehatan yang disediakan di tempat praktik meningkatkan perilaku ibu hamil melakukan pemeriksaan kehamilan karena dengan fasilitas kesehatan yang disediakan sangat mendukung kealam kenyamanan pasien selama melakukan pemeriksaan kehamilah sehingga proses selama melakukan pemeriksaan dan interaksi dengan bidan sangat mendukung apalagi dimasa Pandemi Covid 19 bidan perlu menjaga kesehatan diri sendiri dan tempat praktek sehingga tidak menimbulkan penularan dan tertular kepada ibu hamil yang rentan/beresiko mengalami Covid dan cukup mengancam keselamatan ibu dan bayiBerdasalkan Hasil uji statistic di peroleh $\mathrm{p}$ value adalah $0,035<\alpha(0,05)$, sehingga dapat dinyatakan bahwa ada hubungan yang signifikan antara fasiitas kesehatan yang dimiliki oleh tempat praktek dengan perilaku ibu hamil melakukan pemeriksaan kehamilan (Antenatal Care) pada masa pandemic covid--19 di BPM Hj. Rosnawati, S.ST Tahun 2020.Hasil analisis lebih lanjut didapatkan $\mathrm{OR}=0,097$, artinya ketersediaan fasilitas kesehatan yang dimiliki oleh tempat praktek saat melakukan pemeriksaan kehamilan (Antenatal Care) memiliki peluang 0,097 kali menunjang perilaku ibu hamil rutin melakukan pemeriksaan Kehamilan di banding dengan tidak tersedia fasiitas kesehatan.

Dari hasil observasi peneliti bahwa tempat praktik selalu disterilkan secara rutin, kemudian 


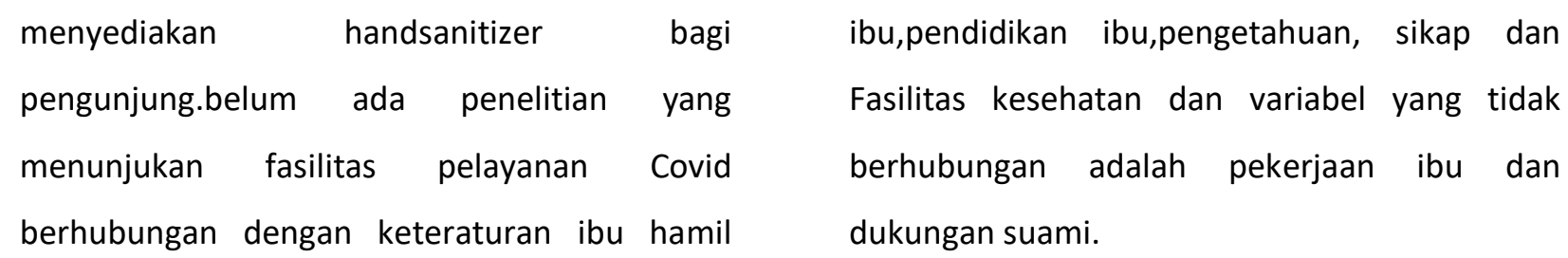
melakukan pemeriksaan kehamilan.

Menurut asumsi peneliti bahwa fasilitas kesehatan yang disediakan di tempat praktik meningkatkan perilaku ibu hamil melakukan pemeriksaan kehamilan karena dengan fasilitas kesehatan yang disediakan sangat mendukung kealam kenyamanan pasien selama melakukan pemeriksaan kehamilah sehingga proses selama melakukan pemeriksaan dan interaksi dengan bidan sangat mendukung apalagi dimasa Pandemi Covid 19 bidan perlu menjaga kesehatan diri sendiri dan tempat praktek sehingga tidak menimbulkan penularan dan tertular kepada ibu hamil yang rentan/beresiko mengalami Covid dan cukup mengancam keselamatan ibu dan bayi fasilitas yang dimiliki sesuai dengan standar SOP dapat meningkatkan kualitas pelayanan ANC bagi ibu hamil sehingga dapat menjamin mutu pelayanan di masyarakat.

\section{SIMPULAN}

Berdasarkan hasil penelitian tentang perilaku ibu hamil melakukan ANC di masa Pandemi Covid 19 adalah bahwa dari 45 responden ibu hamil trimester 3 yang rutin melakukan ANC adalah sebesar 33 orang(73,3\%) dan yang tidak rutin adalah 12 orang $(26,7 \%)$, variabel yang berhubungan secara siqnifikan dengan perilaku ibu hamil melakukan pemeriksaan kehamilan adalah umur

\section{DAFTAR PUSTAKA}

dr. Erna Mulati, M.Sc., CMFM DKK, Pedoman Bagi Ibu Hamil, Bersalin, Nifas dan Bayi Baru Lahir di Era Pandemi COVID-19 KEMENKES RI,2019

kesehatan oleh tenaga kesehatanromkes.kemke s.go.id/pentingnya-pemeriksaan kehamilan-anc-di-fasilitas-kesehatan

https://pogi.or.id/publish/wpcontent/uploads/2020/03/RekomendasiPenanganan Infeksi-COVID-19-padamaternal.pdf

http://www.who.int/reproductivehealth/public ations/maternal perinatal health/ancpositive-pregnancy-experience/en/

https://www.ibi.or.id/media/Materi/WebinarlBI USAIDJalinCovid19/Seri20520Juni2020/P DF201EmiSITUASI PELAYANAN KB PADA MASA PANDEMI COVID-19 ERA NEW NORMAL-compressed.pdf

Notoatmodjo, Soekidjo (2005) , Promosi kesehatan teori da aplikasi,Rineka Cipta,Jakarta,

Nursalam. (2014). Metodologi Penelitian IImu Keperawatan. Jakarta: Salemba Medika Notoatmodjo, S. (2014). Ilmu Perilaku Kesehatan. Jakarta: Rineka Cipta Notoatmodjo, Soekidjo. Metodologi Penelitian Kesehatan. Jakarta: Rineka Cipta; 2012) 
Prawirohardjo, Sarwono. 2009. Ilmu Kebidanan. PT Bina Pustaka Sarwono Prawirohardjo. Jakarta

Rustam, Mochtar. 2012. Sinopsis Obstetri: Obstetri Fisiologi, Obstetri Patologi. Jakarta: EGC.

Manuaba, Ida, Bagus. Et all 2010. Ilmu Kebidanan Penyakit Kandungan dan KB. Jakarta : EGC

Prawirohardjo, Sarwono. 2016. Ilmu Kebidanan. Edisi 4 Cetakan 5. Jakarta: PT Bina Pustaka Sarwono Prawirohardjo

Alamsyah Aziz,2020, Rekomendasi penenganan Infeksi Virs Corona (Covid-19)pada maternal (Hamil,bersalin dan Nifas),pokja infeksi saluran reproduksi

Fasiha. Hubungan pengetahuan dan sikap ibu hamil terhadap pentingnya pemerikasaan Antenatal care di Puskesmas Namtabung Kecamatan Selaru Kabupaten Maluku Tenggara Barat. Global Heakth Science vol. $2 ; 2017$

Maria yosefa(2017) Faktor-faktor yang mempengaruhi perilaku ibu terhadap ketepatan kunjungan antenatal care di puskesmas rekas kabupaten manggarai barat nusa tenggara timur tahun pattipeilohy,skripsi, poltekes yogyakarta

http : //kesehatan oleh tenaga kesehatanromkes.kemkes.go.id/pentingn ya-pemeriksaan-kehamilan-anc-difasilitas-kesehatan)diakses bulan mei 2020
Sinta Putri, DKK (2013), Hubungan Usia Ibu Hamil Dengan Kepatuhan Anc Di Puskesmas Suruh Kabupaten Semarang,jurnal keperawatan Maternitas https://jurnal.unimus.ac.id/index.php/JK $\underline{\text { Mat/article/view/4019 }}$

Khairuni Hikmah,dkk(2019), Analisis Perilaku Yang Memengaruhi Pemeriksaan ANC Pada Ibu Hamil Di Wilayah Kerja Puskesmas Kebayakan Kabupaten Aceh Tengah Provinsi Aceh Tahun 2019, Journal of Healthcare Technology and Medicine Vol. 6 No. 2 Oktober 2020 Universitas Ubudiyah Indonesia e-ISSN : $2615-109 x$

Nur Inayah dkk(2018), Hubungan pendidikan, pekerjaan dan Dukungan Suami terhadap Keteraturan ANCpada Ibu Hamil Trimester 3, Jurnal Health of Studies Vol.3 No1, Maret 2019

Astusti,2014, Hubungan Tingkat Pengetahuan Dan Status Ekonomi Ibu Hamil Dengan Kunjungan K4 Di Wilayah Kerja Puskesmas Durenkabupaten Semarang Syamsiah N, Pustikasari A. 2014 Faktor-faktor yang berhubungan dengan kunjungan antenatal care pada ibu hamil di Puskesmas Kecamatan Kembangan Jakarta Barat tahun

Chaerunnisa AR. Dkk. "Hubungan Perilaku Ibu Hamil terhadap Pemanfaaatan ANC di Puskesmas Mamajang, Kota Makassar" Makalah (tidak dipublikasikan); 2014 